\title{
ADAPTABILITY AND GENOTYPE $\times$ ENVIRONMENT INTERACTION OF SPRING WHEAT CULTIVARS IN CHILE USING REGRESSION ANALYSIS, AMMI, AND SREG
}

\author{
Dalma Castillo ${ }^{1}$ Iván Matus ${ }^{1 *}$, Alejandro del Pozo $^{2}$, Ricardo Madariaga ${ }^{1}$, and Mario Mellado ${ }^{1}$
}

\begin{abstract}
Wheat (Triticum aestivum L.) genetic improvement objectives include obtaining cultivars capable of expressing their maximum potential yield and quality in diverse environments. This make necessary to know and define the environment in which a variety can express its maximum potential yield and quality. The objective of this study was to assess which method is the most efficient to study cultivars response in multiple environments. For this, we analyze the adaptability, stability, and genotype $\times$ environment $(\mathrm{G} \times \mathrm{E})$ interaction effect, grain yield, sedimentation, and wet gluten content of 13 spring wheat cultivars sown in six environments in the central-south and southern zones of Chile during two seasons. The data were analyzed by regression analysis, additive main effects and multiplicative interaction (AMMI), and the sites regression (SREG) model. By this was thus established that SREG analysis is the most efficient for this type of study since, in addition to analyzing stability, adaptability, and effect $(\mathrm{G} \times \mathrm{E})$, it allows identifying the best cultivar. In this case, 'Pandora-INIA' stands out by exhibiting the best yield $\left(7.38 \mathrm{t} \mathrm{ha}^{-1}\right)$, high sedimentation $\left(36.95 \mathrm{~cm}^{3}\right)$, and wet gluten $(41.54 \%)$ indices in all the environments, and this positions it as a variety having both high yield and quality.
\end{abstract}

Key words: AMMI, SREG, G×E, bread wheat, Triticum aestivum.

Y ield and grain quality are two very important characteristics to consider when evaluating a wheat (Triticum aestivum L.) crop. There is great variability in the expression of many characteristics related to wheat quality and yield in different environments (Uhlen et al., 1998; Mellado, 2007), which accounts for the environmental effect on these characteristics.

Wheat grain yield and quality are complex traits in the interaction between a series of biochemical processes and a great number of genes (Stone and Savin, 2000). These traits are defined through the combination of genetic and environmental factors such as soil characteristics, precipitation, fertilization, soil and air temperature, as well as the genotype $\times$ environment $(\mathrm{G} \times \mathrm{E})$ interaction (Peterson et al., 1992; Johansson et al., 2003; Mellado, 2007). Some of the traits that define wheat grain quality are sedimentation and gluten content. The latter refers to the glutenins and gliadins that make up between 80 and $85 \%$ of total wheat proteins and are directly related to final dough viscosity, a trait equally influenced by genetic and environmental factors (Weegels et al., 1996) that is fundamental for the bakery industry's objectives (Shewry

${ }^{1}$ Instituto de Investigaciones Agropecuarias INIA, Casilla 426, Chillán, Chile. *Corresponding author (imatus@inia.cl).

${ }^{2}$ Universidad de Talca, Facultad de Ciencias Agrarias, Casilla 747, Talca, Chile.

Received: 3 November 2011.

Accepted: 25 May 2012. et al., 1995; Hevia et al., 2003; Færgestad et al., 2004). Sedimentation reflects the quality of gluten proteins that is more greatly affected by the environment (Mellado, 2007).

The need to develop cultivars satisfying the bakery industry's requirements calls for plant breeding programs that focus on its objectives to obtain cultivars with high grain quality and good yield (Ramos de Andrade et al., 2001). However, it has been reported that there is a negative correlation between yield and quality, thus making it very difficult to obtain a good quality grain in those high yield potential zones (Saint Pierre et al., 2008).

Wheat cultivation in Chile is carried out in distinct agro-ecological zones known as Coastal Dryland, Inland Dryland, Central Valley, and Andean Foothills extending through various regions of the country (Mellado, 2007). These zones cover diverse climatic conditions ranging from a semi-arid Mediterranean climate (350 mm annual precipitation) to a humid temperate climate with more than $2000 \mathrm{~mm}$ annual precipitation (Dirección Meteorológica de Chile, 2011). Given this climatic diversity, results differ significantly for both yield and quality of wheat cultivars sown in the country. For this reason, it is very important to identify the zone in which a genotype is able to express its full yield and quality potential.

The objective of this study was to analyze the adaptability, stability, and $\mathrm{G} \times \mathrm{E}$ interaction effect on grain yield and quality (wet gluten and sedimentation) of 13 spring wheat cultivars by regression analysis, the additive 
main effects and multiplicative interaction (AMMI) model, and the sites regression (SREG) model to assess which of these methods is the most efficient to study variety response in multiple environments. Regression analysis associates grain yield and quality of each variety with the general mean of all the cultivars known as the environmental index (EI) (Finlay and Wilkinson, 1963). It allows observing variety stability through distinct environments (Calderini and Dreccer, 2002; Kraakman et al., 2004; Acevedo et al., 2005) by considering regression coefficients. Coefficients greater than 1.0 are related to cultivars that are sensitive to environmental changes and adapted to a favorable environment; values less than 1.0 indicate high resistance to environmental changes, environmental insensitivity, and high adaptability to unfavorable environments (Roa de Acevedo and Arcia, 1987; Becker and Léon, 1988; Calderini and Dreccer, 2002).

The AMMI model estimates the magnitude and significance of $\mathrm{G} \times \mathrm{E}$ interaction effects of each variety's response; it essentially combines ANOVA techniques and principal component (PC) analysis into a single model where ANOVA allows studying the main effects of genotypes and environments, while the $\mathrm{G} \times \mathrm{E}$ interaction is treated by multivariate PC (Zobel et al., 1988; Gauch, 1992). On the other hand, the SREG model shows genotype response to specific environments and is very similar to AMMI, except for the fact that this model allows grouping environments with similar performance and graphically identifying which genotype has the greatest potential within each subgroup of environments. That is, it groups genotypes and environments without any crossed interaction. Each variety and environment has a corresponding principal component (PC) with a value to which a vector is assigned. Given this association between genotypes and environments, it is possible to determine the adaptation and/or magnitude of the $\mathrm{G} \times \mathrm{E}$ interaction defined by the linear dependence and association between them (Campos, 2004). These analyses aim to identify high yield and quality genotypes capable of expressing their maximum potential in a wide variety or in specific environments.

\section{MATERIALS AND METHODS}

\section{Genotypes, location, and experiment management}

During the 2003-2004 and 2004-2005 seasons, 13 spring wheat cultivars were evaluated in six contrasting localities in Chile's wheat cultivation zone located between $33^{\circ} 34^{\prime}$ and $38^{\circ} 41^{\prime} \mathrm{S}$ lat, which generated a total of 12 environments (year $\times$ locality). Table 1 shows details of the characterization of each locality. The following spring wheat cultivars were evaluated: 'Centella-INIA', 'Ciko-INIA', 'Dalcahue-INIA', 'Domo-INIA', 'HuañilINIA', 'Huayún-INIA', 'Opala-INIA', 'Otto-Baer', 'Palomar-INIA', 'Pandora-INIA', 'Queltehue-ANASAC',
Table 1. Site location and characteristics.

\begin{tabular}{lcccccc}
\hline Location & Latitude & Longitude & $\begin{array}{c}\text { Altitude } \\
\text { (m a.s.l.) }\end{array}$ & $\begin{array}{c}\text { Soil } \\
\text { classifi- } \\
\text { cation }\end{array}$ & $\begin{array}{c}\text { Annual } \\
\text { precipi- } \\
\text { tation }\end{array}$ & $\begin{array}{c}\text { Average } \\
\text { annual } \\
\text { tempera- } \\
\text { ture }\end{array}$ \\
\hline La Platina & $33^{\circ} 34^{\prime}$ & $70^{\circ} 38^{\prime}$ & 625 & Mollisol & $370^{* *}$ & $15.0^{* *}$ \\
Cauquenes & $35^{\circ} 57^{\prime *}$ & $72^{\circ} 17^{\prime}$, & 166 & Alfisol & $676^{*}$ & $14.7^{*}$ \\
Talca & $35^{\circ} 27^{\prime}$, & $71^{\circ} 30^{\prime}$ & 113 & Alfisol & $693^{*}$ & $14.7^{*}$ \\
Santa Rosa & $36^{\circ} 31^{\prime}$ & $71^{\circ} 54^{\prime}$ & 220 & Andisol & $1272^{*}$ & $13.1^{*}$ \\
Yungay & $37^{\circ} 08^{\prime}$, & $72^{\circ} 00^{\prime}$, & 270 & Andisol & $1786^{*}$ & $13.3^{*}$ \\
Carillanca & $38^{\circ} 41^{\prime}$ & $72^{\circ} 25^{\prime}$ & 200 & Andisol & $2000^{* *}$ & $12.0^{* *}$ \\
\hline
\end{tabular}

${ }^{1}$ Source: USDA (2011).

*del Pozo and del Canto (1999).

***Dirección Meteorológica de Chile (2011).

'Sagaz-INIA', and 'Tamoi-INIA'. Although a complete soil analysis for fertility in all localities was carried out, standard fertilization was employed to meet all possible deficiencies and ensure that wheat plants would always be provided with a good supply of nutrients throughout their cycle. This fertilization consists of the equivalent of $260 \mathrm{~kg} \mathrm{ha}^{-1}$ diammonium phosphate, $90 \mathrm{~kg} \mathrm{ha}^{-1}$ potassium chloride, $200 \mathrm{~kg}$ Sulpomag, $10 \mathrm{~kg}$ boronatrocalcite, and $3 \mathrm{~kg} \mathrm{Zn}$ sulfate applied at sowing, and $340 \mathrm{~kg} \mathrm{NaNO}$ applied at tillering. Irrigation was applied in the localities of La Platina, Talca, Santa Rosa, and Yungay according to crop demand so as not to generate any restriction. Total weed control was carried out, and disease control was not necessary.

Grain yield $\left(\mathrm{t} \mathrm{ha}^{-1}\right)$ was evaluated by harvesting a $2 \mathrm{~m}^{-2}$ plot, sedimentation $\left(\mathrm{cm}^{3}\right)$ was determined by the modified Zeleny method (Parodi and Wulf, 1996), and wet gluten (\%) by employing $10 \mathrm{~g}$ pure flour washed with $5.5 \mathrm{~cm}^{3}$ of $2 \%$ saline solution. This was mixed and put into a gluten washer for $5 \mathrm{~min}$. The residue is made up of proteins, which is dried, weighed, and the weight expressed as a percentage.

\section{Statistical analysis and experimental design}

An incomplete block design was employed in all sites along with four replicates. Adaptability and genotype stability in the distinct environments were estimated by regression analysis, the AMMI (GE biplot) model, and the SREG (GGE biplot) model.

The AMMI and SREG mathematical models are the following (Burgueño et al., 2000):

AMMI Model $\bar{y}_{\mathrm{ij} .}=\mu+\tau_{\mathrm{i}}+\delta_{\mathrm{j}}+\sum_{\mathrm{k}}^{\mathrm{t}}={ }_{1} \lambda_{\mathrm{k}} \alpha_{\mathrm{ik}} \gamma_{\mathrm{jk}}+\bar{\varepsilon}_{\mathrm{ij} .}$

SREG Model $\bar{y}_{\mathrm{ij} .}=\mu+\delta_{\mathrm{j}}+\sum_{\mathrm{k}}^{\mathrm{t}}={ }_{1} \lambda_{\mathrm{k}} \alpha_{\mathrm{ik}} \gamma_{\mathrm{jk}}+\bar{\varepsilon}_{\mathrm{ij} .}$.

where $\bar{y}_{i j}$. is the mean of the $i^{\text {th }}$ cultivar in the $j^{\text {th }}$ environment; $\mu$ is the general mean; $\tau_{\mathrm{i}}$ is the genotypic effect; $\delta_{j}$ is the site effect; $\lambda_{k}\left(\lambda_{1} \geq \lambda_{2} \geq \ldots \geq \lambda_{t}\right)$ are values that allow imposing orthonormal contrasts in the cultivar vectors, $\alpha_{\mathrm{ik}}=\left(\alpha_{1 \mathrm{k}}, \ldots, \alpha_{\mathrm{gk}}\right)$ and sites $\left(\gamma_{\mathrm{jk}}=\gamma_{1 \mathrm{k}}, \ldots, \gamma_{\mathrm{ek}}\right)$, as $\sum_{\mathrm{i}} \alpha_{\mathrm{ik}}^{2}=\sum_{\mathrm{j}} \gamma_{\mathrm{jk}}^{2}=1$ and $\sum_{\mathrm{i}} \alpha_{\mathrm{ik}} \alpha_{\mathrm{ik}}=\sum_{\mathrm{j}} \gamma_{\mathrm{jk}} \gamma_{\mathrm{jk}}{ }^{\prime}=0$, for $\mathrm{k} \neq \mathrm{k}^{\prime} ; \alpha_{\mathrm{ik}}$ and $\gamma_{\text {ik }}$ for $\mathrm{k}=1,2,3, \ldots$ are called "primary", "secondary", "tertiary", etc. effects of cultivars and sites, respectively; $\bar{\varepsilon}_{\mathrm{ij} .}$ is the residual error.

In this study, we used the SAS programs developed 
by Vargas and Crossa (2000) to obtain AMMI analysis making the graphs using PROC PLOT.

\section{RESULTS AND DISCUSSION}

\section{Grain yield}

Mean grain yield of the 13 cultivars showed a wide range of variation in the distinct environments (Table 2). The lowest grain production was obtained in Cauquenes, a dryland zone, while the highest was found in Carillanca, a town located in the southernmost part of the study area where availability of water for cultivation is high. There is a positive linear relationship between environmental index and yield; however, there are significant differences among cultivars (Figure 1). For example, 'Pandora-INIA' was the most productive in all the environments, while 'Otto-Baer' had one of the lowest yields.

In the AMMI analysis for yield, the first two principal components account for $70.37 \%$ of $\mathrm{G} \times \mathrm{E}$ interaction variability (PC1 40.38\% and PC2 29.99\%). This results in a graph (Figure 2a) showing the environmental effect on each genotype (Gauch and Zobel, 1996; Burgueño et al., 2000; Yan and Hunt, 2001; Kaya et al., 2002). This bidimensional Figure 2 is divided into four sections in which cultivars and environments are distributed according to the sign of their respective vectors obtained in the analysis (Tarakanovas and Ruzgas, 2006; Kaya et al., 2006). In general, cultivars

Table 2. Mean yields or environmental index (EI), sedimentation, and wet gluten content of 13 spring wheat cultivars in six localities and two production seasons (2003-2004 and 2004-2005).

\begin{tabular}{lcccc}
\hline Locality & $\begin{array}{c}\text { Growing } \\
\text { season }\end{array}$ & Yield or EI & Sedimentation & Wet gluten \\
\hline \multirow{4}{*}{ La Platina } & $2003-2004$ & $6.26 \pm 0.30$ & $33.75 \pm 2.18$ & $40.51 \pm 1.90$ \\
& $2004-2005$ & $5.17 \pm 0.42$ & $27.25 \pm 1.40$ & $37.62 \pm 1.15$ \\
Cauquenes & $2003-2004$ & $2.61 \pm 0.11$ & $57.93 \pm 2.76$ & $62.55 \pm 1.63$ \\
& $2004-2005$ & $4.71 \pm 0.25$ & $44.13 \pm 3.05$ & $41.81 \pm 1.19$ \\
Talca & $2003-2004$ & $8.33 \pm 0.22$ & $33.62 \pm 1.31$ & $43.67 \pm 1.20$ \\
& $2004-2005$ & $5.52 \pm 0.18$ & $35.71 \pm 1.71$ & $45.90 \pm 1.10$ \\
Santa Rosa & $2003-2004$ & $6.89 \pm 0.20$ & $28.34 \pm 0.96$ & $32.53 \pm 1.20$ \\
& $2004-2005$ & $8.11 \pm 0.23$ & $27.67 \pm 1.08$ & $29.67 \pm 1.83$ \\
Yungay & $2003-2004$ & $7.28 \pm 0.18$ & $27.68 \pm 0.65$ & $35.11 \pm 1.52$ \\
& $2004-2005$ & $5.35 \pm 0.28$ & $31.90 \pm 0.92$ & $36.81 \pm 0.71$ \\
Carillanca & $2003-2004$ & $8.96 \pm 0.13$ & $47.92 \pm 2.48$ & $41.93 \pm 1.10$ \\
& $2004-2005$ & $8.53 \pm 0.16$ & $39.92 \pm 1.82$ & $40.15 \pm 1.05$ \\
\hline
\end{tabular}

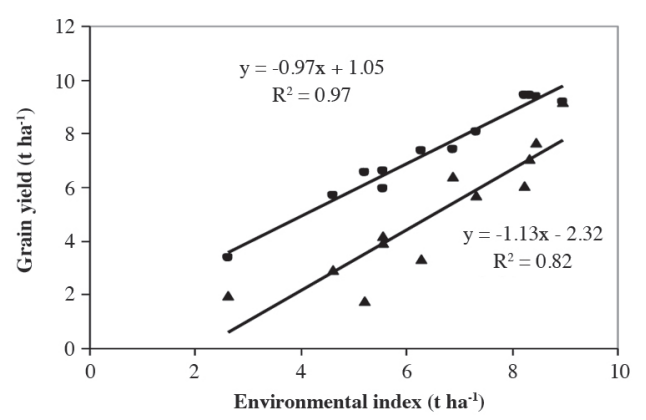

Figure 1. Relationship between environmental index and yield of two contrasting cultivars, Pandora-INIA $(\bullet)$ and Otto-Baer $(\Delta)$. Data for six environments and two growing seasons. exhibit a high degree of yield variability reflected by high dispersion in the biplot. Thus, interesting cultivars are those with $\mathrm{PC} 1$ values higher than zero and classified as high yield, while those with PC1 values lower than zero are classified as low yield and low adaptability (Kaya et al., 2006). Low yield cultivars and environments are located in quadrants I and III of the biplot where 'Otto-Baer' exhibits the longest $\mathrm{PC} 1$ vector in this direction, indicating low adaptability and the lowest yield (Figure 2a). On the other hand, cultivars that are stable or less sensitive to environmental influences are found near the biplot point of origin (Mahalingam et al., 2006; Kaya et al., 2006), and in this case, 'Queltehue-ANASAC' and 'Huayún-INIA'. The 'Tamoi-INIA' expressed a very good yield and good adaptability due to the length of its $\mathrm{PC} 1$ and PC2 vectors.

The SREG yield analysis provides a graph (Figure 2b) that, unlike the AMMI biplot, allows determining
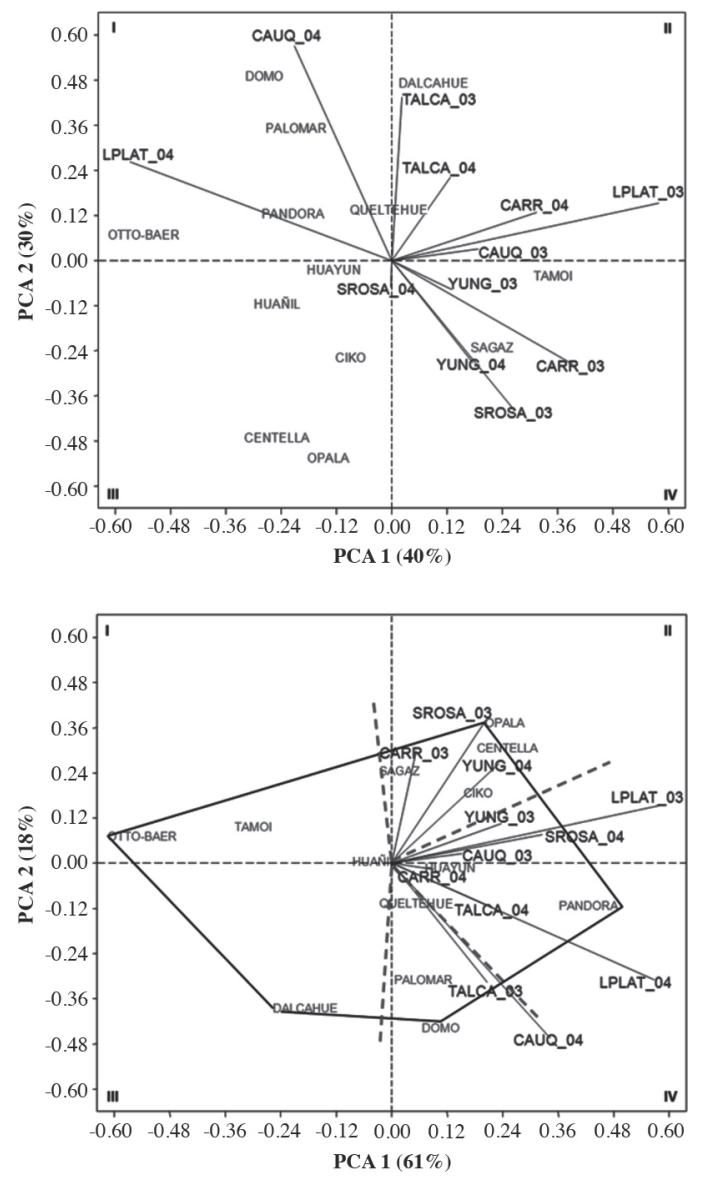

Environments: LPLAT_03: La Platina 2003-2004, LPLAT_04: La Platina 2004-2005, TALCA_03: Talca 2003-2004, TALCA_04: Talca 2004-2005, CAUQ_03: Cauquenes 2003-2004, CAUQ_04: Cauquenes 2004-2005, SROSA_03: Santa Rosa 2003-2004, SROSA_04: Santa Rosa 2004-2005, YUNG_03: Yungay 2003-2004, YUNG_04: Yungay 2004-2005, CARR_03: Carillanca 2003-2004, and CARR_04: Carillanca 2004-2005.

Figure 2a. Biplot Additive Main Effects and Multiplicative Interaction (AMMI) for grain yield of 13 spring wheat cultivars in six environments.

Figure 2b. Biplot Sites Regression Model (SREG) for grain yield of 13 spring wheat cultivars in six environments. 
the variety with the best performance in all environments and distinguishing possible mega-environments formed by the sites. This is achieved by connecting the variety vector points farthest from the origin and then drawing a perpendicular line from this last point to each side of the polygon; thus, environments and cultivars are separated into subgroups, and cultivars in the vertex of each sector correspond to the best performers in the localities making up the mega-environment. Grouping sites produced three mega-environments, the most important one formed by the following environments: Talca 04, Cauquenes 03 , Yungay 03, La Platina 03 and 04, Santa Rosa 04, and Carillanca 04. It is clear from the PC1 vector length for 'Pandora-INIA' in this graph that it was the variety with the highest yield and stability in all environments.

This result coincides with the one obtained in the regression analysis previously carried out as well as with the results of Matus and Vega (2004). These authors analyzed the response of the 'Domo-INIA', 'Tamoi-INIA', 'Huayún-INIA', 'Pandora-INIA', 'Ciko-INA', 'OpalaINIA', and 'Huañil-INIA' cultivars in seven different environments of the country's cultivation area; six of these correspond to our test environments. Mean yield was $7.34 \mathrm{t} \mathrm{ha}^{-1}$, and 'Pandora-INIA' surpassed this value $\left(8.11 \mathrm{t} \mathrm{ha}^{-1}\right)$ in the same way as in our study; furthermore, it showed great stability by exceeding mean yield in each locality, including in those localities exhibiting some type of environmental restriction.

Given the results, it is possible to suggest that 'Pandora-INIA' is a variety with both high yield and adaptability. Two components are associated with the latter characteristic; the first is related to the ability of accumulating sugars in the stem, and the second to the efficiency with which these reserves are mobilized to kernels. This last component is strongly linked to genotype and depends on the number of grains per spike and grain mean weight (Ehdaie and Waines, 1996). In seasons with adequate environmental conditions for plant development, most DM is accumulated before anthesis; however, a variety adapted to adverse conditions would be able to continue accumulating DM and $\mathrm{N}$ during the grain fill period (Przulj and Momellovie, 2003). This would be a 'Pandora-INIA' characteristic enhancing its adaptability potential and favoring grain production in adverse environments.

\section{Quality}

Sedimentation has a significant curvilinear relationship ( $\mathrm{P}$ $<0.01$ ) with yield in both seasons (Figure 3a), and also with EI.The latter relationship is observed in Figure $3 \mathrm{~b}$ and shows the response of contrasting cultivars with 'HuañilINIA' exhibiting the highest sedimentation $\left(42.88 \mathrm{~cm}^{3}\right)$, 'Pandora-INIA' maintaining mean sedimentation (36.95 $\mathrm{cm}^{3}$ ), and 'Domo-INIA' with the lowest sedimentation level $\left(28.58 \mathrm{~cm}^{3}\right)$. The highest sedimentation level was found in Cauquenes, locality with the lowest yield, and
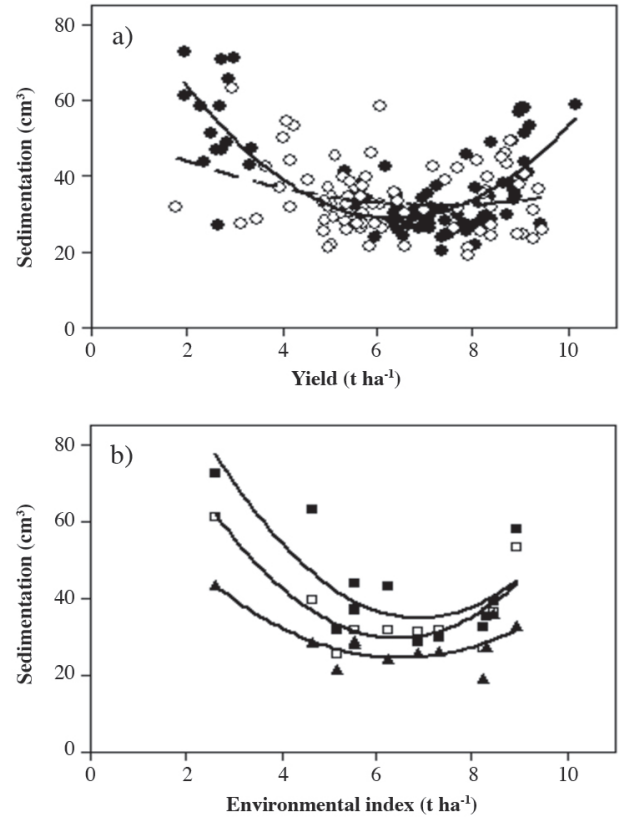

Figure 3. Relationship between sedimentation and: a) Yield for 13 spring wheat cultivars in six environments, 2003-2004 season $\left(O ; y=1.84 x^{2}\right.$. $\left.23.40 \mathrm{x}+103.19, \mathrm{r}^{2}=0.57, \mathrm{P}<0.01\right)$ and 2004-2005 $\left(\bigcirc ; \mathbf{r}^{2}=0.05, \mathrm{P}>\right.$ $0.05)$; b) environmental index of three contrasting cultivars, 2003-2004 and 2004-2005 seasons, cv. Huañil-INIA $\left(\square ; y=0.023 x^{2}-3.21 x+145.6\right.$, $\left.\mathrm{r}^{2}=0.65, \mathrm{P}<0.01\right)$, cv. Pandora-INIA $\left(\square ; \mathrm{y}=0.022 \mathrm{x}^{2}-2.85 \mathrm{x}+121.2, \mathrm{r}^{2}\right.$ $=0.75, \mathrm{P}<0.01)$, and cv. Domo-INIA $\left(\Delta ; \mathrm{y}=0.0124 \mathrm{x}^{2}-1.61 \mathrm{x}+76.7, \mathrm{r}^{2}\right.$ $=0.62, \mathrm{P}<0.01)$.

as yield increases, the sedimentation value decreases, reaching a minimum in Santa Rosa. In the other localities, grain quality increases along with an increase in yield (Figure 3a, Table 2).

Cultivars showed important differences in sedimentation values as reflected in the AMMI analysis biplot result (Figure 4a), where PC1 and PC2 explain $54.02 \%$ and $17.86 \%$ of the interaction, respectively, and with a combined $71.89 \% \mathrm{G} \times \mathrm{E}$. The first and third biplot sections illustrate cultivars with sedimentation levels that are lower than the mean, while the genotype sedimentation index of the second and fourth quadrants are higher than the mean. 'Huañil-INIA' was the variety with the highest sedimentation level and better stability due to the length of its PC1 and PC2 vectors; this coincides with our regression analysis. On the other hand, 'Pandora-INIA' and 'Ciko-INIA' were located near the biplot origin, (low PC2), indicating they were the most stable cultivars.

In SREG sedimentation analysis (Figure 4b), PC1 and PC2 explain $70.57 \%$ and $10.51 \%$, respectively, of the variance and a combined $81.08 \%$ of the variability. By drawing the perpendicular from the origin to the sides of the polygon formed by the cultivars farthest from the biplot center, the perpendicular lines to each side of the figure 4 separate three mega-environments (Figure 4b). The third mega-environment is the most important one since it contains many of the localities: La Platina 04, Talca 04, Cauquenes 04, Yungay 03, Yungay 04, Santa 

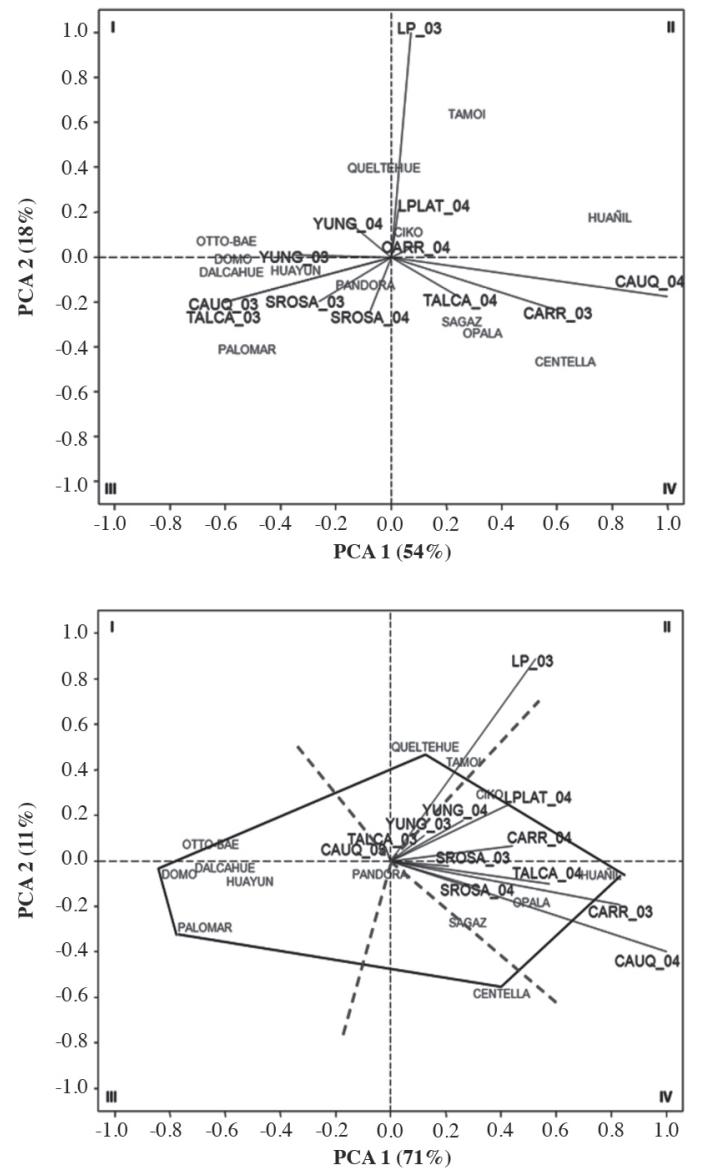

Environments: LPLAT_03: La Platina 2003-2004, LPLAT_04: La Platina 2004-2005, TALCA_03: Talca 2003-2004, TALCA_04: Talca 2004-2005, CAUQ_03: Cauquenes 2003-2004, CAUQ_04: Cauquenes 2004-2005, SROSA_03: Santa Rosa 2003-2004, SROSA_04: Santa Rosa 2004-2005, YUNG_03: Yungay 2003-2004, YUNG_04: Yungay 2004-2005, CARR_03: Carillanca 2003-2004, and CARR_04: Carillanca 2004-2005.

Figure 4a. Biplot Additive Main Effects and Multiplicative Interaction (AMMI) for sedimentation of 13 spring wheat cultivars in six environments.

Figure 4b. Biplot Sites Regression Model (SREG) for sedimentation of 13 spring wheat cultivars in six environments.

Rosa 03, Santa Rosa 04, Carillanca 03, and Carillanca 04. In this mega-environment, 'Huañil-INIA' is the genotype with the highest sedimentation level in all environments; however, 'Pandora-INIA' maintains a level close to the mean, is noted for its high stability, and is located in the center of the biplot.

The SREG analysis results were comparable with those obtained in our prior regression analysis and by Matus and Vega (2004), who determined that 'HuañilINIA' exhibited the best sedimentation index in all environments followed by 'Opala-INIA', 'Ciko-INIA', and 'Pandora-INIA'. However, the latter variety does not exhibit any great differences among environments and maintains a sedimentation level close to the mean, and corroborates data shown in the SREG graph.

Wet gluten content regression analysis shows a variety response similar to that exhibited by sedimentation (Figure 5a). The correlation between gluten content and sedimentation was significant $(\mathrm{P}<0.01)$ in both seasons although the $\mathrm{r}^{2}$ value was lower in the second season $\left(\mathrm{r}^{2}=\right.$ 0.56 and 0.23 , in 2003-2004 and 2004-2005, respectively).

Wet gluten AMMI analysis shows that PC1 and PC2 explain $31.05 \%$ and $23.24 \%$, respectively, and a combined $54.29 \%$ of the variability. Cultivars with a gluten percentage lower than the general mean are found in quadrants I and III of the resulting biplot (Figure 6a). Quadrants II and IV group those cultivars that were higher than the mean. 'Centella-INIA' is located in the point farthest from the center of the biplot (PC1), indicating high gluten content, but the length of its PC2 vector exhibits this variety's instability. 'Opala-INIA' is another high gluten content variety (PC1), but it is much more stable than 'Centella-INIA' (lower PC2). 'PandoraINIA' was located in the general mean, while 'DalcahueINIA' and 'Palomar-INIA' were in the center of the biplot exhibiting high stability but lower gluten level than the abovementioned cultivars.

Figure $6 \mathrm{~b}$ shows the SREG gluten content analysis graph. PC1 and PC2 explain $31.05 \%$ and $23.39 \%$, respectively of the GxE interaction. The perpendiculars drawn from the origin to each side of the polygon formed by joining the farthest genotypes allowed differentiating three mega-environments. In the first, made up of Talca 03, Talca 04, Santa Rosa 03, Santa Rosa 04, Carillanca

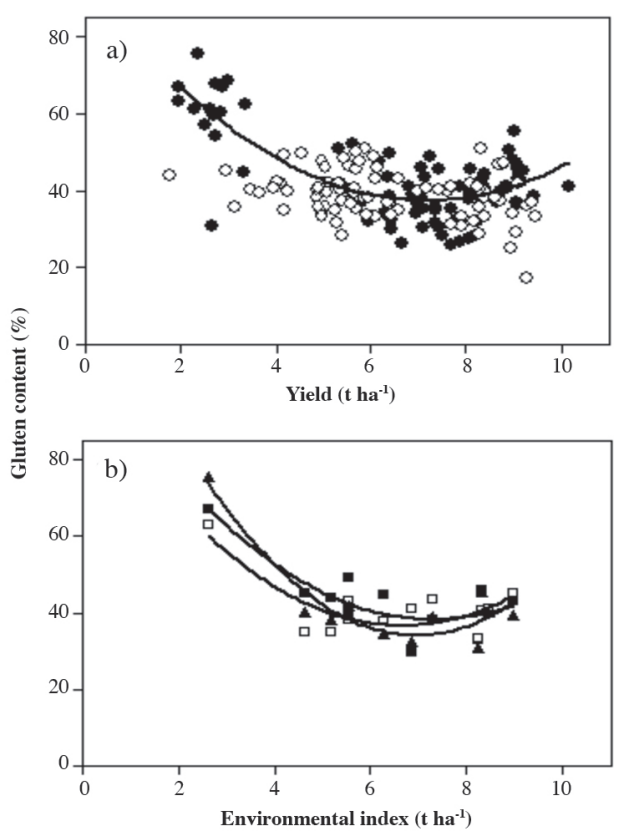

Figure 5. Relationship between wet gluten content and: a) Yield for $\mathbf{1 3}$ spring wheat cultivars in six environments, 2003-2004 $\left(0 ; y=1.11 x^{2}\right.$ 15.86x + 94.19, $\left.\mathrm{r}^{2}=0.58, \mathrm{P}<0.01\right)$ and 2004-2005 $(\bigcirc ; \mathrm{P}>0.05)$ seasons; $\left.\mathrm{b}\right)$ environmental index of three contrasting cultivars, 2003-2004 and 20042005 seasons, Huañil-INIA $\left(\square ; \mathrm{y}=1.32 \mathrm{x}^{2}-19.24 \mathrm{x}+108.5 . \mathrm{r}^{2}=0.75, \mathrm{P}<\right.$ 0.01), Pandora-INIA $\left(\square ; \mathrm{y}=1.45 \mathrm{x}^{2}-19.2 \mathrm{x}+100.4, \mathrm{r}^{2}=0.67, \mathrm{P}<0.01\right)$, and Domo-INIA $\left(\Delta ; y=2.11 x^{2}-29.35 x+136,01, r^{2}=0.87, P<0.01\right)$. 

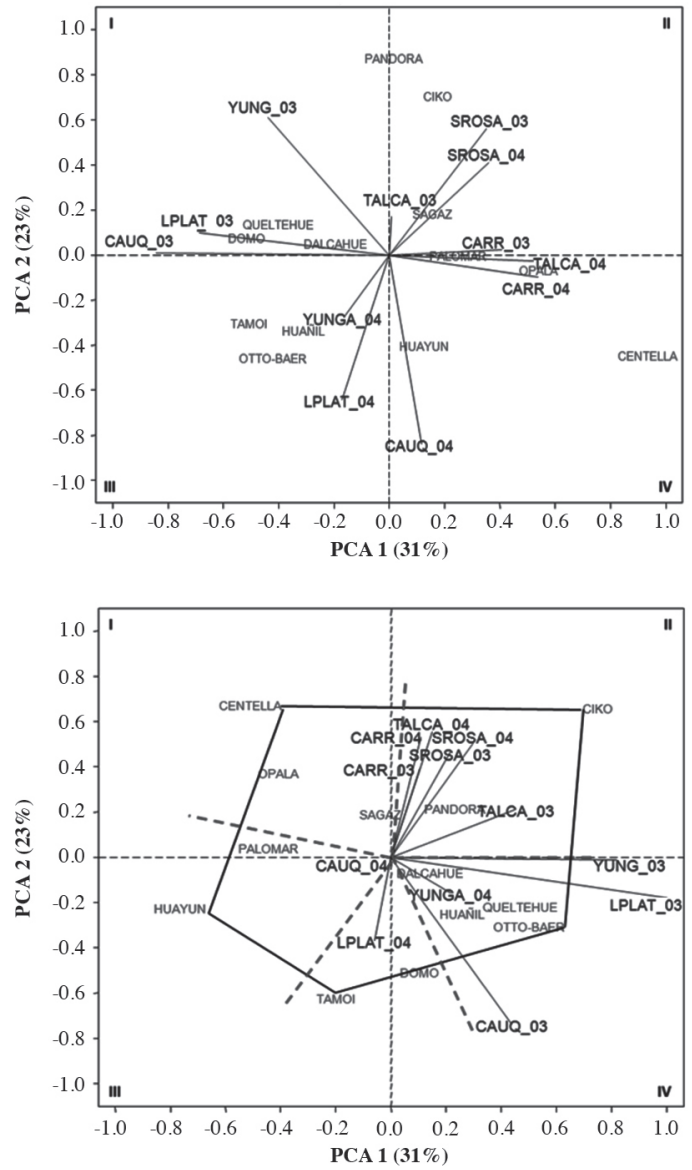

Environments: LPLAT_03: La Platina 2003-2004, LPLAT_04: La Platina 2004-2005, TALCA_03: Talca 2003-2004, TALCA_04: Talca 2004-2005, CAUQ_03: Cauquenes 2003-2004, CAUQ 04: Cauquenes 2004-2005, SROSA 03: Santa Rosa 2003-2004, SROSA_04: Santa Rosa 2004-2005, YUNG_03: Yungay 2003-2004, YUNG_04: Yungay 2004-2005, CARR_03: Carillanca 2003-2004, and CARR_04: Carillanca 2004-2005.

Figure 6a. Biplot Additive Main Effects and Multiplicative Interaction (AMMI) for wet gluten content of 13 spring wheat cultivars in six environments.

Figure 6b. Biplot Sites Regression Model (SREG) for wet gluten content of 13 spring wheat cultivars in six environments.

03, and Carillanca 04, 'Ciko-INIA' stands out as the genotype with the best response because of its notably longer PC1 vector; however, the length of its PC2 was also significant, indicating this variety's great instability. 'Pandora-INIA' also excels with gluten content close to the mean and a greater stability than 'Ciko-INIA'. The latter coincides with data published by Matus and Vega (2004), who determined a gluten mean of $47.34 \%$ in the seven environments. 'Ciko-INIA' showed a higher gluten content than the mean in each site; however, 'PandoraINIA' had values much closer to the mean in each locality and a much lower variation among localities.

Quality is a complex characteristic and the degree of influence of each component determining its expression is affected by the genotype's behavior to a specific environment. Diverse studies point out that climatic conditions during the growing season, especially during the wheat's reproductive period, are very important since they are closely related to the formation and accumulation of protein reserves (Gaido and Dubois, 2008) that have an impact on genotype quality (Finlay et al., 2007). Borghi et al. (1995) point out that in a Mediterranean-type climate, such as the one found in Chile, the G×E interaction has a strong influence and causes important variety response variability for both yield and quality in each season and each planting site.

In general, cultivars exhibited wide response variability to the $\mathrm{G} \times \mathrm{E}$ effect on yield and quality without any direct or positive relationship between these two parameters. However, 'Pandora-INIA' stood out because it exhibited a higher yield than the others in all environments and also maintained the quality-related parameters close to the mean without any important variations from one locality to the other.

A fundamental aspect in cereal genetic improvement is to understand and integrate the effect of $\mathrm{G}$ and $\mathrm{G} \times \mathrm{E}$ in selecting genotypes with enhanced behavior (Barah $e t$ al., 1981; Kang, 1988; Eskridge, 1990; Kang and Pham, 1991; Yan et al., 2000). Many statistical methods have been developed to carry out this type of analysis, such as AMMI analysis (Gauch, 1992) and SREG biplot (Yan and Tinker, 2006). AMMI considers the effects of $G$ and G×E separately, while SREG combines these sources of variation. This makes SREG analysis a tool with high discriminatory power because it integrates $(\mathrm{G}+\mathrm{G} \times \mathrm{E})$, highly effective when evaluating the response of distinct cultivars in multiple environments and not possible with AMMI analysis (Burgueño et al., 2000). The objective of this study was to compare regression analysis, AMMI, and SREG to evaluate adaptability, stability, and $\mathrm{G} \times \mathrm{E}$ interaction on spring wheat grain yield and quality in Chile. Our results coincide with the above mentioned explanation since SREG was the most efficient method to discriminate the best variety and determine that 'PandoraINIA' was the one that stood out above the rest; this is also supported by studies carried out by Matus and Vega (2004) in our country and whose results show that 'Pandora-INIA' is a high yield variety with good grain quality.

\section{CONCLUSIONS}

There are three cultivars that stand out for each one of the analyzed variables: 'Pandora-INIA' for yield, 'HuañilINIA' for sedimentation, and 'Ciko-INIA' for wet gluten content. However, and according to the results obtained with the three applied methodologies, 'Pandora-INIA' was a stable variety in all the environments excelling for its high yield, and maintaining a high level of quality.

SREG analysis was the most efficient and complete methodology to analyze the GxE interaction and allowed determining the variety with the best response in all the environments; this corresponded to 'Pandora-INIA' with 
its good yield, high quality, as well as its high stability in all environments for both seasons.

\section{Adaptabilidad e interacción genotipo $\times$ ambiente} en trigos de primavera utilizando análisis de regresión, AMMI y SREG. Dentro de los objetivos del mejoramiento genético del trigo (Triticum aestivum L.) figura la obtención de variedades capaces de expresar su máximo potencial de rendimiento y calidad en diversos ambientes. Por lo cual es necesario conocer y definir el ambiente en que una variedad puede expresar al máximo su potencial de rendimiento y de calidad. El objetivo de este trabajo fue determinar una metodología eficiente para analizar la respuesta de diversos cultivares de trigo a distintos ambientes. Para ello se analizó la adaptabilidad, estabilidad y la interacción Genotipo $\times$ Ambiente $(\mathrm{G} \times \mathrm{E})$ de 13 variedades de trigo de primavera, sembradas, en seis ambientes de la zona centro sur y sur de Chile, durante dos temporadas, evaluando rendimiento de grano, sedimentación y contenido de gluten húmedo. Los resultados fueron sometidos a análisis de regresión, análisis de efectos principales aditivos e interacción multiplicativa (AMMI) y modelo de regresión de sitios (SREG), estableciendo que el análisis SREG es el más eficiente para este tipo de estudio, ya que además de analizar estabilidad, adaptabilidad y efecto $(\mathrm{G} \times \mathrm{E})$, permite identificar cuál es la mejor variedad. 'PandoraINIA' presentó el mejor rendimiento $\left(7,38 \mathrm{t} \mathrm{ha}^{-1}\right)$, altos índices de sedimentación $\left(36,95 \mathrm{~cm}^{3}\right)$ y gluten húmedo $(41,54 \%)$ en todos los ambientes, siendo la variedad que presenta en conjunto alto rendimiento y alta calidad.

Palabras clave: AMMI, SREG, G $\times$ E, trigo harinero, Triticum aestivum.

\section{LITERATURE CITED}

Acevedo, E., M. Opazo, H. Silva, and P. Silva. 2005. Rendimiento, componentes de rendimiento y resistencia a sequía en trigo (Triticum aestivum L.) Available at http://www.agronomia.uchile. $\mathrm{cl} /$ centros/sap/Archivos/ea/Rendimiento, $\% 20$ componentes $\% 20$ de $\% 20$ rendimiento $\% 20$ y $\% 20$ resistencia $\% 20 a \% 20$ se 1 .pdf (accessed January 2010).

Barah, B.C., H.P. Binswanger, B.S. Rana, and N.G.P. Rao. 1981. The use of risk aversion in plant breeding; concept and application. Euphytica 30:451-458.

Becker, H.C., and J. Léon. 1988. Stability analysis in plant breeding. Plant Breeding 101:1-23.

Borghi, B., M. Corbellini, M. Ciaffi, D. Lafiandra, E. De Stefanis, and D. Sgrulletta. 1995. Effect of heat shock during grain filling on grain quality of bread and durum wheats. Australian Journal of Agricultural Research 46:1365-1380.

Burgueño, J., J. Crossa, and M. Vargas. 2000. SAS programs for graphing GE and GGE biplots. Biometrics and Statistics Unit, Centro Internacional de Mejoramiento de Maíz y Trigo (CIMMYT), México.

Campos, G.J. 2004. Adaptación e interacción genotipo-ambiente de lino (Linum usitatissimum L.) en Chile. Tesis Ingeniero Agrónomo. Universidad de Concepción, Facultad de Agronomía, Chillán, Chile.
Calderini, D., and F. Dreccer. 2002. Choosing genotype, sowing date, and plant density for malting barley. p. 413-443. In Slafer, G., J. Molina Cano, R. Savin, J. Araus, and I. Ramagosa (eds.) Barley science. Recent advances from molecular biology to agronomy of yield and quality. Food Products Press, New York, USA.

Del Pozo, A., and P. Del Canto. 1999. Áreas agroclimáticas y sistemas productivos en la VII y VIII Regiones. Serie Quilamapu $\mathrm{N}^{\circ} 113$. Instituto de Investigaciones Agropecuarias, Centro Regional de Investigación Quilamapu. Ministerio de Agricultura, Santiago, Chile.

Dirección Meteorológica de Chile. 2011. Climas de Chile. Dirección General de Aeronáutica Civil, Dirección Meteorológica de Chile, Santiago, Chile. Available at http://www.meteochile.cl/climas/ climas.html (accessed January 2011).

Ehdaie, B., and J.G. Waines. 1996. Genetic variation for contribution of pre-anthesis assimilates to grain yield in spring wheat. Journal of Genetics and Breeding 50:47-56.

Eskridge, K.M. 1990. Selection of stable cultivars using a safety first rule. Crop Science 30:369-374.

Færgestad, E., N. Solheim, E. Merethe, K Hollung, H. Martens, and A. Uhlen. 2004. Relationships between storage protein composition, protein content, growing season and flour quality of wheat. Journal of the Science of Food and Agriculture 84:877886.

Finlay, G.J., P.R. Bullock, H.D. Sapirstein, H.A. Naeem, A. Hussain, S.V. Angadi, and R.M. Depauw. 2007. Genotypic and environmental variation in grain, flour, dough and bread-making characteristics of western Canadian spring wheat. Canadian Journal of Plant Science 87:679-690.

Finlay, K.W., and G.N. Wilkinson. 1963. The analysis of adaptation in a plant breeding programme. Australian Journal of Agricultural Research 14:742-754

Gaido, Z.A., and M.D. Dubois. 2008. Influencia del estrés térmico en la calidad panadera del trigo: progenies con diferentes niveles de sensibilidad. Agriscientia 25(2):89-96.

Gauch, H.G. 1992. Statistical analysis of regional yield trials: AMMI analysis of factorial designs. Available at http://www.cabdirect. org/abstracts/19931643324.html (accessed June 2009).

Gauch, G.H., and R.W. Zobel. 1996. AMMI analysis of yield trials. p. 85-122. In Kang, M.S., and H.G. Gauch (eds.) Genotype by environment interaction. CRC Press, Boca Raton, Florida, USA.

Hevia, F., M. Mellado, R. Wilckens, M. Berti, and S. Jofré. 2003. Rendimiento de harina y aptitud panadera de seis cultivares de trigo de primavera sembrado en tres ambientes. Agrosur 31(2):3846.

Johansson, E., M.L. Prieto-Linde, G. Svensson, and J.Ö. Jönsson. 2003. Influences of cultivar, cultivation year and fertilizer rate on amount of protein groups and amount and size distribution of mono and polymeric proteins in wheat. Journal of Agricultural Science 140:275-284.

Kang, M.S. 1988. A rank-sum method for selecting high-yielding, stable corn genotypes. Cereal Research Communication 16:113115 .

Kang, M.S., and H.N. Pham. 1991. Simultaneous selection for high yielding and stable crop genotypes. Agronomy Journal 83:161165.

Kaya, Y., M. Akcura, and S. Taner. 2006. GGE-biplot analysis of multi-environment yield trials in bread wheat. Turkish Journal of Agriculture 30:325-337.

Kaya, Y., C. Palta, and S. Taner. 2002. Additive main effects and multiplicative interactions analysis of yield performances in bread wheat genotypes across environments. Turkish Journal of Agriculture 26:275-279.

Kraakman, A.T.W., R.E. Niks, P.M. van den Berg, P. Stam, and F.A. Van Eeuwijk. 2004. Linkage disequilibrium mapping of yield and yield stability in modern spring barley cultivars. Genetics 168:435-446.

Mahalingam, L., S. Mahendran, R. Chandra, and G. Atlin. 2006. AMMI Analysis for stability on grain yield in rice (Oryza sativa L.). International Journal of Botany 2:104-106. 
Matus, I., and A. Vega. 2004. Variedades. In Boletín de trigo 2004. Manejo Tecnológico. Capítulo 1. Boletín INIA N¹14. 188 p. Instituto de Investigaciones Agropecuarias INIA, Chillán, Chile.

Mellado, M. 2007. El trigo en Chile. Colección de Libros INIA $\mathrm{N}^{\circ} 21$. Instituto de Investigaciones Agropecuarias INIA, Centro Regional de Investigación Quilamapu, Chillán, Chile.

Parodi, P., and H. Wulf. 1996. Expresión de la heterosis en la calidad molinera y panadera de híbridos en trigo. Agricultura Técnica 26:97-106.

Peterson, C.J., R.A. Graybosch, P.S. Baenziger, and A.W. Grombacher. 1992. Genotype and environment effects on quality characteristics of hard red winter wheat. Crop Science 32:98-103.

Przulj, N., and V. Momellovie. 2003. Dry matter and nitrogen accumulation and use in spring barley. Plant Soil and Environment 49:36-47.

Ramos de Andrade, A., C.R. Riede, S.M.B. Dos Santos, D. Destro, and I.C. Batista. 2001. Selection for grain yield and quality in segregating generations of wheat. Brazilian Archives of Biology and Technology 44:173-178.

Roa de Acevedo, S., and A. Arcia. 1987. Comportamiento de tres variedades de tomate (Lycopersicon esculentum Mill.) en diferentes años de siembra. Agronomía Tropical 37(4-6):105-115.

Saint Pierre, C., J. Peterson, A. Ross, J.B. Ohm, M. Verhoeven, M. Larson, and B. Hoefer. 2008. White wheat grain quality changes with genotype, nitrogen fertilization, and water stress. Agronomy Journal 100:414-420.

Shewry, P.R., J.A. Napier, and A.S. Tatham. 1995. Seed storage proteins: structures and biosynthesis. Plant Cell 7:945-956.

Stone, P., and R. Savin. 2000. An introduction to the physiologicalecological analysis of wheat yield. p. 3-11. In Satorre, E. and G. Slafer (eds.) Wheat: Ecology and physiology of yield determination. Chapter 1. Viva Books Private Limited, New Delhi, Mumbai, Chennai.
Tarakanovas, P., and V. Ruzgas. 2006. Additive main effect and multiplicative interaction analysis of grain yield of wheat varieties in Lithuania. Agronomy Research 4:91-98.

Uhlen, A.K., R. Hafskjold, A.H. Kalhovd, S. Sahlstrom, A. Longva, and E.M. Magnus. 1998. Effects of cultivar and temperature during grain filling on wheat protein content, composition, and dough mixing properties. Cereal Chemistry 75:460-465.

USDA. 2011. Soil Series Classification Database. United States Department of Agriculture (USDA), Natural Resources Conservation Service (NRCS), Washington DC, USA. Available at http://soils.usda.gov/technical/classification/scfile/index.html (accessed March 2011).

Vargas, M., y J. Crossa. 2000. El análisis AMMI y la gráfica del biplot en SAS. 42 p. Centro Internacional de Mejoramiento de Maíz y Trigo (CIMMYT), México D.F., México.

Weegels, P.L., A.M. Van de Pijpekamp, A. Graveland, R.J Hamer, and J.D Schofield. 1996. Depolymerisation and re-polymerisation of wheat glutenin during dough processing. I. Relationships between glutenin macropolymer content and quality parameters Journal of Cereal Science 23:103-111.

Yan, W., and L.A. Hunt. 2001. Interpretation of genotype x environment interaction for winter wheat yield in Ontario. Crop Science 41:19-25.

Yan, W., L.A. Hunt, Q. Sheng, and Z. Szlavnics. 2000. Cultivar evaluation and mega-environment investigation based on GGE biplot. Crop Science 40:596-605.

Yan, W., and N.A. Tinker. 2006. Biplot analysis of multienvironment trial data: Principles and applications. Canadian Journal of Plant Science 86:623-645.

Zobel, R.W., M.S. Wright, and H.G. Gauch. 1988. Statistical analysis of a yield trial. Agronomy Journal 80:388-393. 